\title{
The influence of inulin on the absorption of nitrogen and the production of metabolites of protein fermentation in the colon
}

\author{
Karen P. Geboes, Gert De Hertogh, Vicky De Preter, Anja Luypaerts, Bert Bammens, Pieter Evenepoel, \\ Yvo Ghoos, Karel Geboes, Paul Rutgeerts and Kristin Verbeke* \\ Laboratory of Digestion and Absorption, Department of Gastroenterology, University Hospital Gasthuisberg, Catholic University \\ of Leuven, Herestraat 49, 3000 Leuven, Belgium \\ (Received 14 November 2005 - Revised 19 June 2006 - Accepted 12 July 2006)
}

\begin{abstract}
In the present study, the production and fate of bacterial metabolites in the colon were investigated in a direct way using two substrates labelled with stable isotopes: lactose $\left[{ }^{15} \mathrm{~N},{ }^{15} \mathrm{~N}\right]$ ureide as a source of labelled ammonia and egg proteins intrinsically labelled with $\left[{ }^{2} \mathrm{H}_{4}\right]$ tyrosine as a precursor of $\left[{ }^{2} \mathrm{H}_{4}\right] p$-cresol. Both ammonia and phenolic compounds are believed to be carcinogenic. Stimulation of carbohydrate fermentation in order to prevent accumulation of these toxic metabolites was induced by inclusion of inulin in a test meal or by addition of inulin to the daily diet, allowing us to distinguish between changes induced by the actual presence of a fermentable carbohydrate and effects caused by a long-term dietary intervention. When a single dose of inulin was administered together with the labelled substrates, a significant increase in faecal ${ }^{15} \mathrm{~N}$ excretion, accompanied by a proportional decrease in urinary ${ }^{15} \mathrm{~N}$ excretion was observed, probably reflecting an enhanced uptake of ammonia for bacterial biosynthesis, since an increased concentration of labelled $\mathrm{N}$ in bacterial pellets was found. A statistically significant reduction of urinary $\left[{ }^{2} \mathrm{H}_{4}\right] p$ cresol excretion was also noted. Upon supplementation of inulin to the daily diet during 4 weeks, however, only a tendency towards decreased urinary excretion of both labelled and unlabelled $p$-cresol was noted. Further studies are warranted to confirm these results in a larger cohort.
\end{abstract}

Carbohydrate fermentation: Colonic nitrogen: Stable isotopes

The lumen of the large intestine is an intensely proteolytic environment. Recent studies have suggested that metabolites derived from bacterial handling of proteins are implicated in the pathogenesis of various diseases. Both ammonia, derived from proteolysis, as well as ureolysis and phenolic compounds, formed out of aromatic amino acids, are important in the pathogenesis of the uraemic syndrome (Vanholder et al. 2001). In vitro studies also suggest a role for metabolites from protein fermentation in the pathogenesis of colon cancer (Visek, 1978; Cummings et al. 1979; Corpet et al. 1995).

Fermentation of carbohydrates may cause a decrease in the production of toxic metabolites from protein fermentation, including ammonia and phenolic compounds, through various mechanisms (Vince \& Burridge, 1980; Cummings \& Bingham, 1987; Weber et al. 1987; MacFarlane et al. 1992). However, studies addressing this topic lead to different results. This is due to the fact that the excretion of ammonia and phenols is influenced by a number of factors besides carbohydrate fermentation, which cannot all be controlled (Cummings et al. 1979; MacFarlane et al. 1992).

In the present study, an attempt was made to study protein fermentation in a direct way using safe and non-radioactive markers. Both the fate of ammonia present in the colon and the bacterial production of phenolic compounds were studied by means of substrates labelled with stable isotopes.
Stimulation of carbohydrate fermentation was induced either by inclusion of inulin in the test meal or by addition of inulin to the daily diet, allowing us to distinguish between changes induced by the actual presence of a fermentable carbohydrate and effects caused by a 4-week dietary intervention.

Inulin-type fructans are fructose polymers of different chain length, which escape digestion in the small intestine due to the $\beta$-configuration of the fructosidic linkages. As a result, about $85-90 \%$ of ingested carbohydrate is likely to reach the colon, where it is readily fermented (Roberfroid, 1999; Cummings et al. 2001). Direct effects attributed to carbohydrate fermentation include an enhanced bacterial growth and thus $\mathrm{N}$ uptake, a decrease in $\mathrm{pH}$ due to SCFA production and a reduction of the enzymes necessary for protein breakdown through a mechanism called catabolite repression (Vince \& Burridge, 1980; Cummings \& Bingham, 1987; Weber et al. 1987; MacFarlane et al. 1992). Inulin is also a prebiotic, which means that it is a non-digestible dietary supplement that modifies the balance of the intestinal microflora, stimulating the growth and/or activity of beneficial organisms for human health and suppressing potentially deleterious bacteria (Cummings et al. 2001; Roberfroid, 2001). The selective growth stimulation of bifidobacteria in the colonic microbiota by the inulin-type fructans was observed both in vitro and in

\footnotetext{
Abbreviations: LU, lactose ureide; PEG, polyethylene glycol.

* Corresponding author: Dr Kristin Verbeke, fax +32 16344399, email Kristin.Verbeke@uz.kuleuven.ac.be
} 
human studies (Roberfroid, 2001). Microbial activity has been studied in continuous-culture systems as well as in faecal slurries. The activities of enzymes such as azoreductase, nitroreductase, $\beta$-glucuronidase and $\beta$-glucosidase, which are thought to favour carcinogen formation in the colon, were evaluated (Cummings et al. 2001). A decrease in enzyme activity was not always observed in dietary intervention studies in human subjects. However, studies of faecal enzyme activities are notoriously difficult to interpret and the in vitro system may well be a better model of what is going on in the proximal gut. Furthermore, whether changes in enzyme activity translate into a changed product formation depends on the substrate availability, $\mathrm{pH}$ and a number of other factors (Cummings et al. 2001). There is a need for more human nutrition studies and/or new markers to investigate the interaction of prebiotics with colon carcinogenesis, since various types of animal models consistently demonstrate a reduced risk in experimentally induced carcinogenesis processes with inulin-type fructans (Van Loo et al. 1999).

In the present study, we investigated the production and fate of bacterial metabolites using two substrates labelled with stable isotopes; lactose $\left[{ }^{15} \mathrm{~N},{ }^{15} \mathrm{~N}\right]$ ureide (LU) as a source of labelled ammonia and egg proteins intrinsically labelled with $\left[{ }^{2} \mathrm{H}_{4}\right]$ tyrosine as a precursor of $\left[{ }^{2} \mathrm{H}_{4}\right] p$-cresol. Both ammonia and phenolic compounds are believed to be carcinogenic (Visek, 1978; Cummings et al. 1979; Corpet et al. 1995).

\section{Materials and methods}

\section{Experimental design}

It was decided to study as many variables as possible in the present study. The laborious work did not allow us to study large cohorts of volunteers. Therefore, the present study has to be considered as a pilot study and further studies are necessary to confirm the findings.

The first part of the study involved the evaluation of the excretion of the labelled markers in twelve healthy volunteers (four men and eight women) upon administration of inulin together with the test meal. The volunteers performed a $24 \mathrm{~h}$ urine collection and a $3 \mathrm{~d}$ stool collection once after ingestion of the pancake test meal containing labelled LU and egg proteins intrinsically labelled with $\left[{ }^{2} \mathrm{H}_{4}\right]$ tyrosine and once again after ingestion of the pancake meal containing an additional 5 g Raftilin HP $^{\circledR}$ (Orafti, Tienen, Belgium).

In the second part of the study, the influence of daily administration of inulin during 4 weeks was investigated in seven healthy volunteers (two men and five women). They received $5 \mathrm{~g}$ Raftilin $\mathrm{HP}^{\circledR}$ three times per $\mathrm{d}$ for 1 month, except on the days the tests were performed. All volunteers collected urine for $24 \mathrm{~h}$ and all stools during $3 \mathrm{~d}$ after ingestion of the test meal. They did this once before the start of the dietary intervention, once after they had been taking inulin for 1 week, once again after 1 month and once more 1 week after having stopped the intake of inulin.

The volunteers kept diet records the week before the first test and in between the following experiments in order to allow a qualitative comparison of dietary intakes. They were allowed to eat their usual diets, but were urged to keep a constant macronutrient composition.
All subjects ingested $1 \mathrm{~g}$ unlabelled LU the evening before each test and then fasted overnight.

\section{Substrates}

The marker molecules were administered in a pancake test meal, with a total energy content of $1369 \mathrm{~kJ}(327 \mathrm{kcal})$, containing $19 \mathrm{~g}$ protein, $6 \mathrm{~g}$ fat and $27 \mathrm{~g}$ carbohydrate. The batter of the pancake was made with two whole eggs intrinsically labelled with $\left[{ }^{2} \mathrm{H}_{4}\right]$ tyrosine. These eggs were obtained by feeding laying hens feed supplemented with $\left[{ }^{2} \mathrm{H}_{5}\right]-$ phenylalanine $(3 \mathrm{~g} / \mathrm{kg}$; mol percent $98 \%$; Euriso-Top, Saint Aubin, France) (labels at all ring-positions). Part of the ingested $\left[{ }^{2} \mathrm{H}_{5}\right]$ phenylalanine was hydroxylated to $\left[{ }^{2} \mathrm{H}_{4}\right]-$ tyrosine by the hens' metabolism and, as a consequence, both marker molecules were incorporated in the egg proteins. The $\left[{ }^{2} \mathrm{H}_{4}\right]$ tyrosine content of each egg was determined by means of GC-MS (trace GC-MS; Thermofinnigan, San José, CA, USA).

Labelled LU (75 mg; synthesised according to the method of Schoorl as modified by Hofmann (1931)) with $\left[{ }^{15} \mathrm{~N},{ }^{15} \mathrm{~N}\right]$ urea obtained from Euriso-Top was added to the pancake batter. Unlabelled LU (1 g) was ingested on the evening before the test in order to induce the proper enzyme activity in the colonic bacteria (Wutzke et al. 1997).

$185 \mathrm{kBq}$ of $\left[{ }^{3} \mathrm{H}\right]$ polyethylene glycol $\left(\left[{ }^{3} \mathrm{H}\right] \mathrm{PEG}\right)$ (NEN Life Science Products Inc., Boston, MA, USA) was added to the test meal as an inert radiolabelled transit marker in order to correct for oro-anal transit time (Krag et al. 1975).

The inulin source in the study was Raftilin HP $^{\circledR}$ (Orafti, Tienen, Belgium), a linear $\beta(2,1)$-linked fructose polymer, terminated by a sucrose residue, purified from chicory root. According to the supplier, Raftilin $\mathrm{HP}^{\circledR}$ contains $>99 \%$ inulin with a degree of polymerisation ranging between 5 and 60 and $<0.5 \%$ glucose, fructose and sucrose.

\section{Sample collection and storage}

Urine samples were collected in plastic containers to which $1 \mathrm{~g}$ neomycin was added in order to prevent bacterial growth. All volunteers were asked to void before consumption of the test meal and this urine collection was used for measurement of the basal $\mathrm{N}$ content and ${ }^{15} \mathrm{~N}$ enrichment. The natural urinary content of $\left[{ }^{2} \mathrm{H}_{4}\right] p$-cresol and $\left[{ }^{2} \mathrm{H}_{4}\right]$ phenol was zero. After ingestion of the pancake, urine was collected during $1 \mathrm{~d}$ in different fractions: $0-6 \mathrm{~h}, 6-10 \mathrm{~h}, 10-24 \mathrm{~h}$. After measurement of the volume, samples were taken and stored at $-20^{\circ} \mathrm{C}$ until analysis.

The volunteers also performed a $72 \mathrm{~h}$ stool collection. Date and time of voiding of stools were noted in a diary. The stools were weighed immediately after voiding and all stools collected on the same day were combined and homogenised before further analysis.

Fresh faecal samples ( $\pm 10 \mathrm{~g}$ for every day of the collection) were diluted tenfold with sterile pyrogen-free water. Homogenisation was performed with a tissue-homogeniser at $20 \mathrm{MHz}$ (M. Zipperer GmbH, Staufen, Germany) for $1 \mathrm{~min}$. The homogenate was ultracentrifuged at $25000 \mathrm{~g}$ for 120 min (MR22i; Jouan, St-Herblain, France) and the supernatant fraction was subsequently filtered through a $0.2 \mu \mathrm{m}$ syringe filter (Supor Acrodisc 32, Gelman Sciences, Ann Arbor, 
MI, USA) in order to discard the ultimate faecal rests and the bacteria. The final filtrate was used for determination of total phenol, total $p$-cresol, $\left[{ }^{2} \mathrm{H}_{4}\right] p$-cresol and $\left[{ }^{2} \mathrm{H}_{4}\right]$ phenol (Evenepoel et al. 1999; Geypens et al. 1999).

Another faecal sample of $10 \mathrm{~g}$ for each day of the collection was immediately freeze-dried. These samples were used for separation into the bacterial, fibre and soluble fractions.

The remainder of the stool collections was diluted with $500 \mathrm{~g}$ sterile pyrogen-free water. After homogenisation, a sample of known weight was removed and freeze-dried. The dried material was weighed again and samples were taken for analysis of $\mathrm{N}$ and radioactivity.

\section{Analyses}

Determination of total nitrogen content and ${ }^{15} \mathrm{~N}$ enrichment in urine, faeces and bacterial pellets. Total $\mathrm{N}$ content and ${ }^{15} \mathrm{~N}$ enrichment of urine and faeces were measured using an elemental analyser (ANCA-SL; PDZ Europa Ltd, Northwich, Cheshire, UK) coupled with both a thermal conductor detector (PDZ Europa Ltd) and a stable isotope ratio mass spectrometer (20-20 IRMS; PDZ Europa Ltd). A known volume of urine $(15 \mu \mathrm{l})$, faeces (freeze-dried, about $7 \mathrm{mg}$ ) or bacterial pellets (freeze-dried, about $3 \mathrm{mg}$ ) was oxidised in the presence of $\mathrm{O}_{2}$ at $1000^{\circ} \mathrm{C}$. The combustion products thereafter passed through a second furnace containing $\mathrm{Cu}$ at $600^{\circ} \mathrm{C}$ where excess $\mathrm{O}_{2}$ was absorbed and nitrogen oxides were reduced to elemental $\mathrm{N}$. Total $\mathrm{N}$ content was measured by means of a thermal conductor detector, whereas the ${ }^{15} \mathrm{~N}$ enrichment was determined by means of an isotope ratio mass spectrometer detector, coupled to the combustion unit of the elemental analyser.

The results for the urinary and faecal collections were expressed as total $\mathrm{N}(\mathrm{g})$ and percentage of administered dose ${ }^{15} \mathrm{~N}$. Total $\mathrm{N}$ in the bacterial fraction was expressed in $\mathrm{mg} / \mathrm{g}$ bacteria and ${ }^{15} \mathrm{~N}$ excretion was expressed in $\mathrm{ng} / \mathrm{mg}$.

Determination of urinary and faecal total p-cresol, total phenol, $\left[{ }^{2} \mathrm{H}_{4}\right] \mathrm{p}$-cresol and $\left[{ }^{2} \mathrm{H}_{4}\right]$ phenol. The concentrations of $p$-cresol, phenol, $\left[{ }^{2} \mathrm{H}_{4}\right] p$-cresol and $\left[{ }^{2} \mathrm{H}_{4}\right]$ phenol were determined by means of GC-MS (Trace GC MS; Thermofinnigan, San José, CA, USA) according to the procedure described by Geypens et al. (1999). Briefly, both for urinary and faecal analysis, samples with a volume of $950 \mu$ l were taken. After adjusting the $\mathrm{pH}$ to 1 with $\mathrm{H}_{2} \mathrm{SO}_{4}$ (Merck KgaA, Darmstadt, Germany), the solution was heated for $30 \mathrm{~min}$ at $90^{\circ} \mathrm{C}$ in order to deproteinise and hydrolyse the conjugated phenols. After cooling down to room temperature, $50 \mu \mathrm{l}$ of $2,6 \mathrm{di}$ methylphenol $(20 \mathrm{mg} / 100 \mathrm{ml}$ water) (Sigma-Aldrich Chemie $\mathrm{GmbH}$, Steinheim, Germany) was added as internal standard and the phenols were extracted with $1 \mathrm{ml}$ ethyl acetate (Merck KgaA, Darmstadt, Germany). Thereafter, the ethyl acetate layer was dried over anhydrous sodium sulfate and $0.5 \mu \mathrm{l}$ of this solution was analysed on a GC-MS.

The results were expressed as total $p$-cresol and phenol $(\mathrm{mg})$ excreted in urine or in faeces. For $\left[{ }^{2} \mathrm{H}_{4}\right] p$-cresol and $\left[{ }^{2} \mathrm{H}_{4}\right]$ phenol, the results were expressed as percentage of administered dose of $\left[{ }^{2} \mathrm{H}_{4}\right]$ tyrosine.

Finally, it was decided to report urinary excretion of labelled $\mathrm{N}$ separately for the $0-6 \mathrm{~h}$ and the $6-24 \mathrm{~h}$ urine collections, to allow for differentiation between small-bowel and colonic events. On the other hand, there was no need to examine the urinary excretion of labelled phenolic compounds in the separate fractions, since both $\left[{ }^{2} \mathrm{H}_{4}\right] p$-cresol and $\left[{ }^{2} \mathrm{H}_{4}\right]$-phenol can only be derived from colonic bacterial metabolism.

Determination of faecal $\left[{ }^{3} H\right]$ polyethylene glycol. The $\left[{ }^{3} \mathrm{H}\right] \mathrm{PEG}$ content in stool was measured by liquid-scintillation counting (Packard Tricarb Liquid Scintillation Spectrometer, model 3375; Packard Instruments Inc., Downers Grove, IL, USA) after oxidation to ${ }^{3} \mathrm{H}$-labelled water (Packard Sample Oxidiser, model 306; Packard Instruments Inc.).

${ }^{3} \mathrm{H}$-labelled water contents in stool were expressed as percentage of administered dose recovered over $72 \mathrm{~h}$ and were used to correct for gastrointestinal transit by dividing the cumulative percentage of administered dose of ${ }^{15} \mathrm{~N}$ recovered over $72 \mathrm{~h}$ by the cumulative percentage of administered dose of ${ }^{3} \mathrm{H}$ recovered over $72 \mathrm{~h}$ (i.e. corrected faecal ${ }^{15} \mathrm{~N}$ excretion). Supplementation of inulin to the daily diet may influence oroanal transit, whereas a single dose of inulin will probably not. Nevertheless, oro-anal transit time may vary on a day-to-day basis. Inclusion of the $\left[{ }^{3} \mathrm{H}\right] \mathrm{PEG}$ marker allows us to distinguish between a true change in faecal ${ }^{15} \mathrm{~N}$ excretion and a change caused by an alteration of transit time (Krag et al. 1975).

Separation of the faeces into different fractions. A sample of $250 \mathrm{mg}$ freeze-dried faecal material was taken and thoroughly mixed for $10 \mathrm{~min}$ with $15 \mathrm{ml}$ formylsaline (1\% formol in $0.9 \%$ saline) and $0.15 \mathrm{ml}$ of $10 \%$ sodium lauryl sulfate. The mixture was filtered through a $150 \mu \mathrm{m}$ filter (Varian Inc., Palo Alto, CA, USA) under vacuum and the residue was washed with $15 \mathrm{ml}$ formyl saline, shaken and filtered again. This procedure was repeated twice and, as a result, about $90 \mathrm{ml}$ filtrate was obtained.

The fraction remaining on top of the filter was the fibre fraction and was kept for further analysis. The filtrate was ultracentrifuged at $25000 \mathrm{~g}$ for $36 \mathrm{~min}$. The supernatant fraction, containing the water-soluble compounds, was discarded, while the sediment, containing the bacteria, was dissolved in $2 \mathrm{ml}$ sterile pyrogen-free water. After weighing, the sediment was freeze-dried and the dried material was weighed again (Stephen \& Cummings, 1980a). Samples of the remaining fibre fraction and the freeze-dried bacterial fraction were examined for the presence of bacteria.

Examination of the faecal fractions. Nine paired samples from the fibre fraction and the bacterial fraction were examined for the presence of bacteria using light microscopy and the Gram stain technique. Air-dried, heat-fixed smears of all samples were stained first with crystal violet (Sigma-Aldrich Chemie GmbH, Steinheim, Germany) and then with iodine solution (Sigma-Aldrich Chemie $\mathrm{GmbH}$ ). Following rinsing with an alcohol-acetone mixture, staining with Safranin (Sigma-Aldrich Chemie $\mathrm{GmbH}$ ) was performed. The smears were then analysed in a blinded manner without prior knowledge of the origin of the samples.

Additionally, three paired samples were examined with PCR analysis. Classical DNA extraction was performed by adding $0.5 \mathrm{ml}$ proteinase $\mathrm{K}$ solution $(0.2 \mathrm{mg} / \mathrm{ml})$ (Sigma-Aldrich Chemie $\mathrm{GmbH}$ ). Samples were incubated overnight at $55^{\circ} \mathrm{C}$ in a moving water-bath. The proteinase $\mathrm{K}$ solution was subsequently inactivated by heating up to $95^{\circ} \mathrm{C}$ for $10 \mathrm{~min}$. The actual extraction was performed by the application of phenol and chloroform-isoamylalcohol (24:1) (Sigma-Aldrich 
Chemie $\mathrm{GmbH}$ ). Afterwards, DNA was precipitated in a $10 \mathrm{M}$-ammonium acetate solution (Sigma-Aldrich Chemie $\mathrm{GmbH}$; VWR, Haasrode, Belgium) mixed with $100 \%$ ethanol at $-20^{\circ} \mathrm{C}$. Following two episodes of ultracentrifugation (at $40800 \mathrm{~g}$ ) and washing, DNA pellets were dried and dissolved in $50 \mu \mathrm{l}$ water and finally stored at $-20^{\circ} \mathrm{C}$.

For PCR analysis, $2 \mu \mathrm{l}$ DNA of each sample, $10 \mu \mathrm{l} \mathrm{PCR}$ Master Mix (Promega Corporation, Madison, WI, USA), $0 \cdot 2 \mu \mathrm{l}$ Jenssen 1 primer and $0 \cdot 2 \mu$ l Jenssen 2 primer (Eurogentec, Seraing, Belgium) were dissolved in $7.6 \mu \mathrm{l}$ distilled water. Both primers are complementary to conserved regions of the $16 \mathrm{~S}$ and $23 \mathrm{~S}$ gene, bordering spacer regions between those genes, with repeated appearance (of variable length) on the chromosome. $16 \mathrm{~S}$ and $23 \mathrm{~S}$ are important respectively for the small and large subunit of bacterial ribosomes. The sequence for Jenssen1 primer is $5^{\prime}$-GAA-GTC-GTA-ACAACG- $3^{\prime}$. The sequence for Jenssen 2 primer is $5^{\prime}$-CAA-GGCATC-CAC-CGT-3'. PCR analysis consisted of heating for $10 \mathrm{~min}$ at $94^{\circ} \mathrm{C}$, twenty-five cycles $\left(94^{\circ} \mathrm{C}, 1 \mathrm{~min} ; 55^{\circ} \mathrm{C}\right.$, $4 \mathrm{~min} ; 72^{\circ} \mathrm{C}, 2 \mathrm{~min}$ ), followed by $7 \mathrm{~min}$ at $72^{\circ} \mathrm{C}$ and cooling until $4^{\circ} \mathrm{C}$. PCR products were visualised using agarose gel electrophoresis. The gel was prepared using 0.25 agarose and $25 \mathrm{ml}$ Tris Acetate EDTA (TAE) buffer (40 mM-tris (hydroxymethyl)-aminomethane, $10 \mathrm{mM}$-sodium acetate anhydrous, 1 mM-EDTA). The solution was boiled until the agarose was dissolved and poured into a mall for coagulation. Samples for analysis were introduced in the gel and the gel was placed in an electrophoresis device for $30 \mathrm{~min}$ at $90 \mathrm{~V}$.

\section{Statistical analysis}

All results were expressed as median plus interquartile range and non-parametric statistical analysis was used (Friedman ANOVA and Wilcoxon test; $P$ is significant at $\alpha=0 \cdot 05$; Statistica 6.0, Statsoft Inc. 1984-2001, Tulsa, OK, USA).

\section{Results}

\section{Examination of the faecal fractions}

Light microscopy confirmed the presence of large numbers of bacterial colonies in all the samples of the bacterial fraction. In the fibrous residue occasional bacteria or small colonies were visualised in only two out of nine samples.

PCR analysis confirmed the presence of bacterial DNA in the three samples of the bacterial fraction and was negative in two out of three samples of the fibre fraction.
Effect of the presence of inulin in the meal (n 12)

Total nitrogen and ${ }^{15} \mathrm{~N}$ enrichment in urine. Table 1 shows the results of total $\mathrm{N}$ and ${ }^{15} \mathrm{~N}$ excretion in urine after simultaneous administration of inulin and labelled LU in twelve volunteers. The daily urinary total $\mathrm{N}$ excretion amounted to $10 \mathrm{~g}$ in baseline conditions as well as in the presence of inulin. On the other hand, a statistically significantly lower $24 \mathrm{~h}$ cumulative urinary excretion of the label was found when inulin was present in the test meal (Wilcoxon test; $P=0.02)$. Urine had been collected in $0-6 \mathrm{~h}, 6-10 \mathrm{~h}$ and $10-24 \mathrm{~h}$ fractions, since this allowed us to investigate different events during transit separately: the $0-6 \mathrm{~h}$ urine collection is said to refer to passage through the small bowel, whereas the later collections would reflect colonic events. The 6$24 \mathrm{~h}$ urine fraction was collected in two fractions $(6-10 \mathrm{~h}$ and $10-24 \mathrm{~h}$ ) in order not to obscure a possible early effect of inulin. However, we observed a decrease in urinary ${ }^{15} \mathrm{~N}$ excretion after inulin intake from the $6-10 \mathrm{~h}$ collection onwards. Therefore, it was reasonable to combine both fractions and to present the data as a $6-24 \mathrm{~h}$ collection. Upon ingestion of inulin, a statistically significant decrease in urinary excretion of the label was found in the $6-24 \mathrm{~h}$ collection (Wilcoxon test; $P=0 \cdot 04$ ).

Total nitrogen and ${ }^{15} \mathrm{~N}$ enrichment in faeces. Complete faecal collections were obtained in nine out of twelve volunteers. Stool weight, faecal dry weight, total $\mathrm{N}$ excretion and $\mathrm{N}$ density were not influenced by inclusion of inulin into the test meal (Table 2). However, a statistically significantly higher $72 \mathrm{~h}$ cumulative faecal excretion of ${ }^{15} \mathrm{~N}$ was found when inulin was present in the test meal. This difference was not caused by an increase in transit, since no higher recovery of $\left[{ }^{3} \mathrm{H}\right] \mathrm{PEG}$ was found when inulin was present in the test meal (Wilcoxon test; NS). It was only when inulin was present in the meal that reliable measurements of both total $\mathrm{N}$ and labelled $\mathrm{N}$ were found in the bacterial pellets (Table 2).

Total ${ }^{15} \mathrm{~N}$ excretion. The decrease in urinary ${ }^{15} \mathrm{~N}$ excretion was compensated by an increase in faecal excretion of the labelled compound (Tables 1 and 2). No difference in total excretion of the marker was found (53.13 (interquartile range $47 \cdot 26-62.05) \%$ in baseline conditions $v$. 54.42 (interquartile range $47 \cdot 13-56 \cdot 20) \%$ when inulin was present in the meal; Wilcoxon test; NS), which means that addition of inulin did not cause any difference in retention of the label in the human body $\mathrm{N}$ pool.

Total and labelled phenol and p-cresol in urine. As was expected, the urinary excretion of total phenol and $p$-cresol

Table 1. Effect of inclusion of inulin into the test meal on urinary excretion of nitrogen and ${ }^{15} \mathrm{~N}$ in twelve subjects (Medians and interquartile ranges (IQR))

\begin{tabular}{|c|c|c|c|c|c|}
\hline & \multicolumn{2}{|c|}{ Baseline conditions } & \multicolumn{2}{|c|}{ In the presence of inulin } & \multirow[b]{2}{*}{$P^{*}$} \\
\hline & Median & IQR & Median & IQR & \\
\hline Urinary N loss (g/24h) & $10 \cdot 48$ & $8.91-11.60$ & $9 \cdot 82$ & $8 \cdot 72-10 \cdot 23$ & NS \\
\hline Cumulative $\%{ }^{15} \mathrm{~N}$ recovered over $24 \mathrm{~h}$ (\% administered dose) & 55.63 & $44 \cdot 84-58 \cdot 30$ & 41.40 & $35 \cdot 42-42 \cdot 21$ & 0.02 \\
\hline Cumulative $\%{ }^{15} \mathrm{~N}$ recovered in the $0-6 \mathrm{~h}$ collection (\% administered dose) & $13 \cdot 19$ & $8 \cdot 83-18 \cdot 74$ & 10.97 & $8.08-13.86$ & NS \\
\hline Cumulative $\%{ }^{15} \mathrm{~N}$ recovered in the $6-24 \mathrm{~h}$ collection (\% administered dose) & $40 \cdot 44$ & $35.07-41.75$ & $27 \cdot 77$ & $25 \cdot 38-31.93$ & 0.04 \\
\hline
\end{tabular}

${ }^{*}$ Wilcoxon test, $\alpha=0.05$. 
Table 2. Effect of inclusion of inulin into the test meal on faecal parameters, including excretion of nitrogen and ${ }^{15} \mathrm{~N}$, and on the excretion of total and labelled nitrogen in the bacterial fraction in nine subjects

(Medians and interquartile ranges (IQR))

\begin{tabular}{|c|c|c|c|c|c|}
\hline & \multicolumn{2}{|c|}{ Baseline conditions } & \multicolumn{2}{|c|}{ In the presence of inulin } & \multirow[b]{2}{*}{$P^{*}$} \\
\hline & Median & IQR & Median & IQR & \\
\hline Stool wt (g/72h) & 298 & $155-365$ & 183 & $171-237$ & NS \\
\hline Faecal dry wt (\%) & 24 & $22-28$ & 22 & $19-28$ & NS \\
\hline Cumulative $\%\left[{ }^{3} \mathrm{H}\right] \mathrm{PEG}$ excreted $/ 72 \mathrm{~h}$ (\% administered dose) & $58 \cdot 79$ & $55 \cdot 00-65 \cdot 20$ & 39.42 & $32.90-69.88$ & NS \\
\hline Faecal N loss $(g / 72 h)$ & 3.58 & $2 \cdot 15-4 \cdot 22$ & $2 \cdot 39$ & $1.90-2.68$ & NS \\
\hline $\mathrm{N}$ density (\% dry wt) & $5 \cdot 1$ & $4.3-5.9$ & 4.7 & $4 \cdot 4-4 \cdot 7$ & NS \\
\hline Cumulative $\%{ }^{15} \mathrm{~N}$ recovered in faeces $/ 72 \mathrm{~h}$ (\% administered dose) & $6 \cdot 18$ & $4 \cdot 83-8 \cdot 88$ & $17 \cdot 82$ & $11 \cdot 91-21 \cdot 21$ & 0.04 \\
\hline${ }^{15} \mathrm{~N}$ density (\% dry wt) & 0.005 & $0.003-0.007$ & 0.008 & $0.004-0.014$ & NS \\
\hline \multicolumn{6}{|l|}{ Total $\mathrm{N}$ in the bacterial fraction ( $\mathrm{mg} / \mathrm{g}$ bacterial solids) } \\
\hline Day 1 & NA & & 36 & $27-43$ & \\
\hline Day 2 & NA & & 25 & $21-30$ & \\
\hline Day 3 & NA & & 32 & $29-35$ & \\
\hline \multicolumn{6}{|l|}{${ }^{15} \mathrm{~N}$ in the bacterial fraction ( $\mathrm{ng} / \mathrm{mg}$ bacterial solids) } \\
\hline Day 1 & NA & & $6 \cdot 7$ & $2 \cdot 7-16 \cdot 7$ & \\
\hline Day 2 & NA & & $24 \cdot 6$ & $14.5-25.92$ & \\
\hline Day 3 & NA & & $8 \cdot 12$ & $3 \cdot 9-12 \cdot 1$ & \\
\hline
\end{tabular}

PEG, polyethylene glycol; NA, not applicable.

*Wilcoxon test, $\alpha=0.05$.

was not influenced by a single administration of $5 \mathrm{~g}$ inulin (Table 3). However, a tendency towards a decreased urinary excretion of $\left[{ }^{2} \mathrm{H}_{4}\right]$ phenol was noted upon addition of inulin, and a statistically significantly lower production of $\left[{ }^{2} \mathrm{H}_{4}\right] p$ cresol was found upon simultaneous administration of inulin.

\section{Effect of daily administration of inulin during 4 weeks (n 7)}

Total nitrogen and ${ }^{15} \mathrm{~N}$ enrichment in urine. The urinary excretion of total $\mathrm{N}$ and ${ }^{15} \mathrm{~N}$ during long-term administration of inulin is shown in Table 4. The daily urinary $\mathrm{N}$ excretion was similar throughout the study and varied around $10 \mathrm{~g} /$ $24 \mathrm{~h}$. In addition, no statistically significant difference in $24 \mathrm{~h}$ cumulative urinary excretion of the labelled $\mathrm{N}$ was found at any occasion.

Total nitrogen and ${ }^{15} \mathrm{~N}$ enrichment in faeces. Upon inclusion of $3 \times 5 \mathrm{~g}$ inulin per $\mathrm{d}$ in the diet, no statistically significant difference in stool weight, faecal dry weight or oroanal transit was found (Table 5). Total $\mathrm{N}$ excretion and excretion of the labelled marker were not influenced by the diet intervention. The contents of total $\mathrm{N}$ and labelled $\mathrm{N}$ in the bacterial fraction were below the limit of reliable detection of the ANCA-SL elemental analyser (PDZ Europa Ltd).

Total ${ }^{15} N$ excretion. Since the total excretion of the marker (i.e. cumulative urinary excretion $/ 24 \mathrm{~h}+$ cumulative faecal excretion/72h) was similar in each of the test conditions, there was no difference in retention of the label in the human body $\mathrm{N}$ pool (i.e. 100 - total excretion of the marker) (Table 5).

Total and labelled phenol and p-cresol in urine and faeces. In this part of the study we also evaluated faecal excretion of phenolic compounds, because previous investigators have suggested that faecal excretion of phenolic compounds adequately reflected protein fermentation whereas urinary excretion did not (Birkett et al. 1996).

A tendency towards a decrease in urinary excretion of both total $p$-cresol and labelled $p$-cresol was noted. Statistical significance was not obtained (Table 6). No increase in faecal excretion of $p$-cresol or labelled $p$-cresol was observed. Neither urinary nor faecal excretion of phenol was altered by inclusion of inulin into the meal. Labelled phenol was hardly ever recovered in faeces.

\section{Discussion}

Colonic fermentation of proteins results in the formation of ammonia, nitrosamides, thiol and phenol compounds which are generally believed to be toxic to human metabolism.

Besides the characteristics of the bacterial flora and colonic transit time, the available fermentable carbohydrates: $N$ ratio

Table 3. Effect of inclusion of inulin into the test meal on the excretion of labelled and unlabelled phenol and $p$-cresol in twelve subjects

(Medians and interquartile ranges (IQR))

\begin{tabular}{|c|c|c|c|c|c|}
\hline & \multicolumn{2}{|c|}{ Baseline conditions } & \multicolumn{2}{|c|}{ In the presence of inulin } & \multirow[b]{2}{*}{$P^{*}$} \\
\hline & Median & IQR & Median & IQR & \\
\hline Phenol in urine (mg/24h) & 9.51 & $4 \cdot 31-11 \cdot 24$ & 7.68 & $5 \cdot 30-14 \cdot 15$ & NS \\
\hline$p$-Cresol in urine $(\mathrm{mg} / 24 \mathrm{~h})$ & $29 \cdot 07$ & $22 \cdot 23-54 \cdot 95$ & $46 \cdot 29$ & $12 \cdot 26-63 \cdot 07$ & NS \\
\hline$\left[{ }^{2} \mathrm{H}_{4}\right]$ phenol in urine (\% administered dose of tyrosine/24 $\mathrm{h}$ ) & 1.93 & $1.04-2.02$ & $1 \cdot 17$ & $0.00-1.46$ & 0.06 \\
\hline$\left[{ }^{2} \mathrm{H}_{4}\right] p$-cresol in urine (\% administered dose of tyrosine/24 $\mathrm{h}$ ) & 1.77 & $1 \cdot 14-2 \cdot 45$ & 0.63 & $0.34-1.00$ & 0.04 \\
\hline
\end{tabular}

*Wilcoxon test, $\alpha=0.05$ 
Table 4. Effect of long-term administration of inulin on the urinary excretion of nitrogen and ${ }^{15} \mathrm{~N}$ in seven subjects (Medians and interquartile ranges (IQR))

\begin{tabular}{|c|c|c|c|c|c|c|c|c|c|}
\hline & \multicolumn{2}{|c|}{ Baseline conditions } & \multicolumn{2}{|c|}{1 Week inulin $(3 \times 5 \mathrm{~g})$} & \multicolumn{2}{|c|}{1 Month inulin $(3 \times 5 \mathrm{~g})$} & \multicolumn{2}{|c|}{1 Week stop } & \multirow[b]{2}{*}{$P^{*}$} \\
\hline & Median & IQR & Median & IQR & Median & IQR & Median & IQR & \\
\hline$N$ excretion $(g / 24 h)$ & 9.82 & $8 \cdot 21-10 \cdot 71$ & $8 \cdot 36$ & $7.92-9.64$ & $10 \cdot 05$ & $6.90-11.13$ & $8 \cdot 71$ & $8 \cdot 26-15 \cdot 84$ & NS \\
\hline $\begin{array}{l}\text { Cumulative \% of }{ }^{15} \mathrm{~N} \text { recovered } \\
\text { over } 24 \mathrm{~h}(\% \text { administered dose) }\end{array}$ & 53.61 & $41.51-57.21$ & $42 \cdot 80$ & $40 \cdot 33-49 \cdot 15$ & $52 \cdot 02$ & $42 \cdot 70-54 \cdot 62$ & $56 \cdot 10$ & $37.74-66.01$ & NS \\
\hline $\begin{array}{l}\text { Cumulative } \%{ }^{15} \mathrm{~N} \text { recovered in the } \\
0-6 \mathrm{~h} \text { collection (\% administered dose) }\end{array}$ & $12 \cdot 48$ & $7 \cdot 92-16 \cdot 32$ & $11 \cdot 82$ & $10 \cdot 40-14 \cdot 24$ & $11 \cdot 86$ & $7 \cdot 92-12 \cdot 25$ & 11.97 & $8.58-13.58$ & NS \\
\hline $\begin{array}{l}\text { Cumulative } \%{ }^{15} \mathrm{~N} \text { recovered in the } \\
6-24 \mathrm{~h} \text { collection (\% administered dose) }\end{array}$ & $40 \cdot 57$ & $33.89-41.57$ & 31.56 & $27 \cdot 99-40 \cdot 18$ & $39 \cdot 69$ & $30 \cdot 36-43 \cdot 36$ & $39 \cdot 73$ & $32 \cdot 68-53.69$ & NS \\
\hline
\end{tabular}

${ }^{*}$ Friedman ANOVA, $\alpha=0.05$.

has been found to be an important factor influencing the fermentation process. Many in vitro studies have addressed several of the issues regarding protein and carbohydrate fermentation, by altering $\mathrm{pH}$ of faecal incubations or manipulating $\mathrm{N}$ or carbohydrate supply (Vince \& Burridge, 1980; Vince et al. 1990; Walker et al. 2005). These studies allow us to look into specific effects of changes in the gut environment separately and have provided important information regarding SCFA production and the composition of bacterial flora, events that remain very difficult to study in vivo. Both in vitro and in vivo studies investigated the ability of fermentable carbohydrates to decrease the final concentration of products of protein fermentation. Fermentable carbohydrates are believed to influence protein fermentation both by increasing the bacterial uptake of intermediary metabolites of protein breakdown and by decreasing bacterial metabolism of proteins.

The former effect was often evaluated by measuring the faecal $\mathrm{N}$ excretion. As energy is largely derived from carbohydrate fermentation, it is believed that administration of fermentable carbohydrates stimulates bacterial growth and incorporation of ammonia into the bacteria, resulting in an increased faecal N excretion (Cummings et al. 1979; Vince et al. 1990; Weber, 1997). However, it is important to keep in mind that an increase in faecal $\mathrm{N}$ excretion is not necessarily due to an increased bacterial uptake of $\mathrm{N}$, but can also be caused by certain physical properties of the non-digestible carbohydrate. For instance, some carbohydrates increase the viscosity of the intestinal contents in the small bowel, causing a decreased digestion of nutrients, including proteins, resulting in a higher amount of $\mathrm{N}$ reaching the colon and hence a higher faecal N excretion (Schneeman, 1999; Vince et al. 1990). Similarly, carbohydrates causing an acceleration of colonic transit will also lead to an increased faecal $\mathrm{N}$ excretion, without affecting protein fermentation (Stephen \& Cummings, 1980b; Weber, 1997). Hence, it is important to carefully select the carbohydrate used to influence colonic fermentation. In the present study, inulin was chosen as the fermentable carbohydrate, because previous studies had shown that inulin does not influence digestion in the small bowel and does not accelerate colonic transit (Den Hond et al. 2000; Geboes et al. 2003).

Ammonia in the colon originates from proteolysis as well as from ureolysis. In the present study, lactose $\left[{ }^{15} \mathrm{~N},{ }^{15} \mathrm{~N}\right]$ ureide was used to evaluate the fate of ammonia. Upon oral administration, the molecular bond between the carbohydrate moiety and urea in LU has been shown to resist enzymic degradation in the human upper gastrointestinal tract (Wutzke et al. 1997). When the labelled glycosyl ureide reaches the colon, it is degraded by bacterial enzymes to $\left[{ }^{15} \mathrm{~N},{ }^{15} \mathrm{~N}\right]$ urea, which further undergoes rapid hydrolysis with

Table 5. Effect of long-term administration of inulin on the faecal parameters, excretion of nitrogen and ${ }^{15} \mathrm{~N}$ in faeces, and total ${ }^{15} \mathrm{~N}$ excretion (i.e. sum of cumulative recovery/72 $\mathrm{h}$ in urine and faeces) in seven subjects

(Medians and interquartile ranges (IQR))

\begin{tabular}{|c|c|c|c|c|c|c|c|c|c|}
\hline & \multicolumn{2}{|c|}{ Baseline conditions } & \multicolumn{2}{|c|}{1 Week inulin $(3 \times 5 \mathrm{~g})$} & \multicolumn{2}{|c|}{1 Month inulin $(3 \times 5 \mathrm{~g})$} & \multicolumn{2}{|c|}{1 Week stop } & \multirow[b]{2}{*}{$P^{*}$} \\
\hline & Median & IQR & Median & IQR & Median & IQR & Median & IQR & \\
\hline Stool wt (g/72h) & 298 & $224-359$ & 353 & $298-408$ & 246 & $191-364$ & 256 & $195-319$ & NS \\
\hline Faecal dry wt (\%) & 24 & $21-29$ & 24 & $21-25$ & 25 & $24-28$ & 25 & $23-27$ & NS \\
\hline $\begin{array}{l}\text { Cumulative } \%\left[{ }^{3} \mathrm{H}\right] \mathrm{PEG} \text { recovered } / 72 \mathrm{~h} \\
\text { (\% administered dose) }\end{array}$ & 59.03 & $58.55-67 \cdot 25$ & $54 \cdot 29$ & $27 \cdot 32-72 \cdot 20$ & 63.23 & $26 \cdot 54-82 \cdot 18$ & 49.72 & $48 \cdot 15-67 \cdot 28$ & NS \\
\hline Faecal N excretion ( $g / 72 h)$ & 3.79 & $2 \cdot 81-4 \cdot 30$ & $4 \cdot 11$ & $3.58-5 \cdot 10$ & 3.94 & $2 \cdot 48-4 \cdot 10$ & 3.07 & $2.43-4.08$ & NS \\
\hline $\mathrm{N}$ density (\% dry wt) & $5 \cdot 1$ & $4.4-5.9$ & $5 \cdot 6$ & $4.6-5.9$ & $5 \cdot 3$ & $4.7-5 \cdot 8$ & 5.7 & $5 \cdot 3-5 \cdot 9$ & NS \\
\hline $\begin{array}{l}\text { Cumulative } \%{ }^{15} \mathrm{~N} \text { recovered over } 72 \mathrm{~h} \\
\text { (\% administered dose) }\end{array}$ & 4.86 & $4.82-7.49$ & 9.53 & $8 \cdot 34-10 \cdot 70$ & $8 \cdot 14$ & $4.08-10 \cdot 28$ & 8.67 & $6.04-11.32$ & NS \\
\hline Corrected faecal ${ }^{15} \mathrm{~N}$ excretion & 0.13 & $0.10-0.35$ & 0.18 & $0.15-0.22$ & 0.14 & $0.12-0.21$ & $0 \cdot 17$ & $0.13-0.23$ & NS \\
\hline${ }^{15} \mathrm{~N}$ density (\% dry wt) & 0.005 & $0.003-0.006$ & 0.006 & $0.003-0.007$ & 0.005 & $0.003-0.006$ & 0.007 & $0.004-0.008$ & NS \\
\hline Total ${ }^{15} \mathrm{~N}$ excretion (\%) & $58 \cdot 70$ & $44.88-65.39$ & 52.53 & $50 \cdot 75-54.42$ & 58.45 & $52 \cdot 09-61.73$ & $62 \cdot 14$ & $49.84-75 \cdot 29$ & NS \\
\hline
\end{tabular}

PEG, polyethylene glycol.

${ }^{*}$ Friedman ANOVA, $\alpha=0.05$ 
Table 6. Effect of long-term administration of inulin on the excretion of phenol and $p$-cresol in urine and faeces in seven subjects (Medians and interquartile ranges (IQR))

\begin{tabular}{|c|c|c|c|c|c|c|c|c|c|}
\hline & \multicolumn{2}{|c|}{ Baseline conditions } & \multicolumn{2}{|c|}{1 Week inulin $(3 \times 5 \mathrm{~g})$} & \multicolumn{2}{|c|}{1 Month inulin $(3 \times 5 \mathrm{~g})$} & \multicolumn{2}{|c|}{1 Week stop } & \multirow[b]{2}{*}{$P^{*}$} \\
\hline & Median & IQR & Median & IQR & Median & IQR & Median & IQR & \\
\hline Phenol in urine (mg/24h) & $4 \cdot 20$ & $3 \cdot 30-5 \cdot 45$ & $3 \cdot 29$ & $2 \cdot 62-5.98$ & 3.54 & $3.02-4.58$ & 3.68 & $2 \cdot 96-4 \cdot 24$ & NS \\
\hline$p$-Cresol in urine $(\mathrm{mg} / 24 \mathrm{~h})$ & $32 \cdot 25$ & $14.43-54 \cdot 61$ & $29 \cdot 44$ & $16 \cdot 83-36 \cdot 83$ & $22 \cdot 33$ & $18 \cdot 64-39 \cdot 47$ & 24.85 & $22 \cdot 61-32 \cdot 13$ & NS \\
\hline $\begin{array}{l}{\left[{ }^{2} \mathrm{H}_{4}\right] \text { phenol in urine (\% of administered }} \\
\text { dose tyrosine recovered over } 24 \mathrm{~h} \text { ) }\end{array}$ & 0.22 & $0.16-0.41$ & 0.50 & $0.33-0.68$ & 0.20 & $0.15-0.27$ & 0.12 & $0.09-0.58$ & NS \\
\hline $\begin{array}{l}{\left[{ }^{2} \mathrm{H}_{4}\right] p \text {-cresol in urine (\% of administered }} \\
\text { dose tyrosine recovered over } 24 \mathrm{~h} \text { ) }\end{array}$ & $0 \cdot 81$ & $0.47-0.92$ & 0.54 & $0.44-0.62$ & 0.51 & $0.48-0.57$ & 0.55 & $0.43-0.66$ & NS \\
\hline Phenol in faeces $(\mathrm{mg} / 72 \mathrm{~h})$ & 0.22 & $0.18-0.27$ & 0.52 & $0.13-0.59$ & 0.43 & $0.40-0.49$ & 0.15 & $0.10-0.31$ & NS \\
\hline$p$-Cresol in faeces $(\mathrm{mg} / 72 \mathrm{~h})$ & $9 \cdot 65$ & $3 \cdot 29-24.69$ & $17 \cdot 21$ & $4.55-29.00$ & $9 \cdot 29$ & $7 \cdot 54-19 \cdot 08$ & $13 \cdot 33$ & $6 \cdot 34-23 \cdot 70$ & NS \\
\hline $\begin{array}{c}{\left[{ }^{2} \mathrm{H}_{4}\right] p \text {-cresol in faeces (\% administered }} \\
\text { dose tyrosine recovered over } 72 \mathrm{~h} \text { ) }\end{array}$ & 0.78 & $0.37-0.97$ & 0.89 & $0.76-1 \cdot 30$ & 0.71 & $0.57-1.08$ & 0.44 & $0.31-0.96$ & NS \\
\hline
\end{tabular}

${ }^{*}$ Friedman ANOVA, $\alpha=0.05$.

the production of ${ }^{15} \mathrm{NH}_{3}$. In this way, labelled LU is an efficient vehicle to deliver a known amount of labelled ammonia into the colon.

However, in the present results, a fraction (10\%) of the administered dose of ${ }^{15} \mathrm{~N}$ was consistently found in the $0-6 \mathrm{~h}$ urine collection, suggesting absorption of the marker in the small intestine. Other investigators have identified glucose $\left[{ }^{13} \mathrm{C}\right]$ ureide in urine upon oral administration of lactose $\left[{ }^{13} \mathrm{C}\right]$ ureide (Heine et al. 1995; Morrison et al. 2003). It is assumed that lactase, a brush-border enzyme in the small bowel, converts LU into glucose ureide which is absorbed in the small intestine and excreted in urine without further metabolism in the human body. Although the methods used in the present study did not allow identification of the chemical nature of the label in urine, we assume that most of the label recovered in the $0-6 \mathrm{~h}$ urine collection is present in the form of glucose $\left[{ }^{15} \mathrm{~N},{ }^{15} \mathrm{~N}\right]$ ureide. As a consequence, the excretion of ${ }^{15} \mathrm{~N}$ in the $6-24 \mathrm{~h}$ urine collection is a more appropriate indicator of the absorption of ammonia in the large bowel.

The second substrate used consisted of egg proteins, intrinsically labelled with $\left[{ }^{2} \mathrm{H}_{4}\right]$ tyrosine. Even in physiological conditions, some degree of malabsorption exists upon oral administration of egg proteins so that a small proportion is delivered to the colon and degraded by the bacterial flora (Evenepoel et al. 1999). Bacterial metabolism of tyrosine results in the formation of phenol and $p$-cresol. These compounds are either excreted in faeces or absorbed through the colonic mucosa, detoxified by either glucuronide or sulfate conjugation in the colonic mucosa and the liver, and subsequently excreted in urine (Cummings et al. 1979). As a consequence, both urinary and faecal excretions reflect the production of phenolic compounds and hence the degree of bacterial fermentation of tyrosine.

The results of the present study indicate that inclusion of inulin in a meal causes other effects on protein handling in the colon than a dietary intervention for 4 weeks does.

In the first part of the present study, a single dose of inulin was administered together with the labelled substrates. In this case, it was expected that fermentation of the carbohydrate would provide energy to the bacteria, resulting in an increased uptake of ammonia. Simultaneously, bacterial fermentation of proteins may be influenced by changes in colonic $\mathrm{pH}$, by catabolite repression and by an increased uptake of amino acids or intermediary metabolites (Vince et al. 1980; Cummings \& Bingham, 1987; Weber et al. 1987; MacFarlane et al. 1992). A significant increase in faecal ${ }^{15} \mathrm{~N}$ excretion, accompanied by a proportional decrease in urinary ${ }^{15} \mathrm{~N}$ excretion, was observed. Since no effect of inulin was observed on transit time, stool weight or faecal dry weight, it can be assumed that the variations in ${ }^{15} \mathrm{~N}$ excretion were not caused by an acceleration of colonic transit, but were due to alterations in the bacterial metabolism. This was confirmed by measurement of $\mathrm{N}$ and labelled $\mathrm{N}$ in the bacterial fraction of faeces. Reliable measurements of $\mathrm{N}$ and labelled $\mathrm{N}$ were obtained only when the volunteers had ingested inulin simultaneously with the labelled substrate. The content of $\mathrm{N}$ and labelled $\mathrm{N}$ in the bacterial pellets was below the limit of reliable measurements on every other occasion, including all the experiments in the long-term dietary intervention study. This is due to the small size of the bacterial fraction recovered in a $250 \mathrm{mg}$ freezedried fresh faecal sample. However, the fact that reliable measurements were obtained whenever inulin was ingested together with the labelled marker indicates that an increased bacterial fixation of $\mathrm{N}$ occurs when carbohydrate is fermented.

Simultaneous administration of inulin with the test meal (single dose) also resulted in a statistically significant reduction of urinary $\left[{ }^{2} \mathrm{H}_{4}\right] p$-cresol excretion. Faecal recovery of labelled phenolic compounds was low, and the amount of labelled phenolic compounds present in the bacterial fraction would be below detection limits. Therefore, we cannot prove that the decrease in urinary $\left[{ }^{2} \mathrm{H}_{4}\right] p$-cresol is caused by an enhanced uptake of tyrosine for bacterial biosynthesis, a hypothesis that has been put forward by other authors (Cummings et al. 1979; Birkett et al. 1996).

In the second part of the present study, the influence of a 4week dietary intervention with inulin was evaluated. Inulin was never ingested on the morning of the test or administered together with the test meal, in order to exclude effects caused by fermentation of the carbohydrate. It was expected that the inclusion of inulin into the diet would cause a change in protein fermentation products through a modification of the composition of the colonic bacterial populations, accompanied by changes in microbial enzyme activity (Jenkins et al. 1999; Cummings et al. 2001; Roberfroid, 2001). Dietary intervention with inulin is known to selectively stimulate the growth of bifidobacteria (Gibson et al. 1995; Bouhnik et al. 1996). 
In the present study, a mean increase in stool weight of $32 \mathrm{~g} / \mathrm{d}$ was observed upon inclusion of $15 \mathrm{~g}$ inulin into the diet during 1 week, representing a value of approximately $2 \mathrm{~g}$ stool weight increase per $\mathrm{g}$ inulin consumed. These results confirmed previous studies investigating the effects of addition of inulin to the diet during 1 or 2 weeks (Gibson et al. 1995; Den Hond et al. 2000). However, this tendency towards an increase in faecal bulk was lost when inulin was taken for a longer period.

Previous investigators generally assumed that an increase in stool weight after stimulation of carbohydrate fermentation was caused by an increase in bacterial biomass (Gibson et al. 1995; Den Hond et al. 2000). However, it was shown that inclusion of inulin in the diet changed the relative proportions of bacterial species but did not cause an increase in total bacterial counts (Gibson et al. 1995; Bouhnik et al. 1996). The results of our long-term dietary intervention study are in agreement with these observations, since we did not observe increased faecal excretion of either total or labelled N, which would reflect bacterial uptake of ammonia and hence bacterial growth.

A tendency towards a decreased urinary excretion of both labelled and unlabelled $p$-cresol was noted in the present study, which may reflect a change in microbial activity. However, statistical significance was not obtained. Once again, the effect was most clear after inclusion of inulin into the diet during 1 week.

In conclusion, the results of the present study indicate that lactose $\left[{ }^{15} \mathrm{~N},{ }^{15} \mathrm{~N}\right]$ ureide is an appropriate tool to investigate the fate of colonic ammonia. Egg proteins, intrinsically labelled with $\left[{ }^{2} \mathrm{H}_{4}\right]$ tyrosine, may provide an appropriate tool to study changes in the production of protein fermentation metabolites. However, the low overall recovery of the label is an important drawback. Using these two substrates, we were able to show that inulin influences the colonic metabolism of dietary protein and $\mathrm{N}$ it is ingested with. On the other hand, systematic intake of inulin did not induce changes in the bacterial metabolism of protein. Further studies that measure both bacterial populations and excretion of the labelled markers are currently being performed.

\section{Acknowledgements}

The present study was carried out with financial support from the Commission of the European Communities, specific RTD programme 'Quality of Life and Management of Living Resources', QLK1-2001-00431 'Stable isotope applications to monitor starch digestion and fermentation for the development of functional foods'. It does not necessarily reflect its views and in no way anticipates the Commission's future policy in this area.

\section{References}

Birkett A, Muir J, Phillips J, Jones G \& O’Dea K (1996) Resistant starch lowers faecal concentrations of ammonia and phenols in humans. Am J Clin Nutr 63, 766-772.

Bouhnik Y, Flourie B, Riottot M, Bisetti N, Gailing MF, Guibert A, Bornet F \& Rambaud JC (1996) Effects of fructo-oligosaccharides ingestion on fecal bifidobacteria and selected metabolic indexes of colon carcinogenesis in healthy humans. Nutr Cancer 26, 21-26.

Corpet DE, Yin Y, Zhang X, Remesy C, Stamp D, Medline A, Thompson L, Bruce WR \& Archer MC (1995) Colonic protein fermentation and promotion of colon carcinogenesis and thermolyzed casein. Nutr Cancer 23, 271-281.

Cummings JH \& Bingham SA (1987) Dietary fibre, fermentation and large bowel cancer. Cancer Surv 6, 601-621.

Cummings JH, Hill MJ, Bone ES, Branch WJ \& Jenkins DJ (1979) The effect of meat protein and dietary fiber on colonic function and metabolism II. Bacterial metabolites in faeces and urine. Am J Clin Nutr 32, 2094-2101.

Cummings JH, Macfarlane GT \& Englyst HN (2001) Prebiotic digestion and fermentation. Am J Clin Nutr 73, 415S-420S.

Den Hond E, Geypens B \& Ghoos Y (2000) Effect of high performance chicory inulin on constipation. Nutr Res 20, 731-736.

Evenepoel P, Claus D, Geypens B, Hiele M, Geboes K, Rutgeerts P \& Ghoos Y (1999) Amount and fate of egg protein escaping assimilation in the small intestine of humans. Am J Physiol 277, G935-G943.

Geboes KP, Luypaerts A, Rutgeerts P \& Verbeke K (2003) Inulin is an ideal substrate for a hydrogen breath test to measure the orocaecal transit time. Aliment Pharmacol Ther 18, 721-729.

Geypens B, Claus D, Gorris N, Evenepoel P, Luypaerts A, Rutgeerts P \& Ghoos Y (1999) Determination of deuterated phenylalanine and tyrosine in egg protein by GCQ. J High Resol Chromatogr 22, 465-468.

Gibson GR, Beatry ER, Wang X \& Cummings JH (1995) Selective stimulation of bifidobacteria in the human colon by oligofructose and inulin. Gastroenterology 108, 975-982.

Heine WE, Berthold HK \& Klein PD (1995) A novel stable isotope breath test: ${ }^{13} \mathrm{C}$-labeled glycosyl ureides used as noninvasive markers of intestinal transit time. Am J Gastroenterol 90, 93-98.

Hofmann E (1931) Ueber den Abbau von glucoseureid durch Bacterien (About the dismantling of glucose ureide by bacteria). Biochem Zeitschr 243, 416-422.

Jenkins DJA, Kendall CWC \& Vuksan V (1999) Inulin, oligofructose and intestinal function. $J$ Nutr 129, 1431S-1433S.

Krag E, Krag B \& Lenz K (1975) A comparison of stable and ${ }^{3} \mathrm{H}-$ labelled PEG 4000 as non absorbable water phase markers in the human ileum and faeces. Scand J Gastroenterol 10, 105-108.

MacFarlane GT, Gibson GR \& Cummings JH (1992) Comparison of fermentation reactions in different regions of the human colon. J Appl Bacteriol 72, 57-64.

Morrison DJ, Dodson B, Preston T \& Weaver LT (2003) Gastrointestinal handling of glycosyl $\left[{ }^{13} \mathrm{C}\right]$ ureides. Eur J Clin Nutr 57, $1017-1024$.

Roberfroid MB (1999) Caloric value of inulin and oligofructose. J Nutr 129, 1436S-1437S.

Roberfroid MB (2001) Prebiotics: preferential substrates for specific germs? Am J Clin Nutr 73, Suppl. 2, 406S-409S.

Schneeman BO (1999) Fiber, inulin and oligofructose: similarities and differences. J Nutr 129, Suppl. 7, 1424S-1427S.

Stephen AM \& Cummings JH (1980a) The microbial contribution to human faecal mass. J Med Microbiol 13, 45-56.

Stephen AM \& Cummings JH (1980b) Mechanism of action of dietary fibre in the human colon. Nature 284, 283-284.

Vanholder R, Argilés A, Baurmeister U, et al. (2001) Uremic toxicity: present state of the art. Int J Artif Organs 24, 695-725.

Van Loo J, Cummings J, Delzenne N, et al. (1999) Functional food properties of non-digestible oligosaccharides: a consensus report from the ENDO project (DGXII AIRII-CT94-1095). Br J Nutr 81, $121-132$.

Vince AJ \& Burridge SM (1980) Ammonia production by intestinal bacteria: the effects of lactose, lactulose and glucose. J Med Microbiol 13, 177-191.

Vince AJ, McNeil NI, Wager JD \& Wrong OM (1990) The effect of lactulose, pectin, arabinogalactan and cellulose on the production of organic acids and metabolism of ammonia by intestinal bacteria in a faecal incubation system. Br J Nutr 63, 17-26. 
Visek WJ (1978) Diet and cell growth modulation by ammonia. Am J Clin Nutr 31, S216-S220.

Walker AW, Duncan SH, McWilliam Leitch EC, Child MW \& Flint $\mathrm{HJ}$ (2005) $\mathrm{pH}$ and peptide supply can radically alter bacterial populations and short-chain fatty acid ratios within microbial communities from the human colon. Appl Environ Microbiol 71, $3692-3700$.

Weber FL Jr (1997) Effects of lactulose on nitrogen metabolism. Scand J Gastroenterol 32, Suppl. 222, 83-87.
Weber FL Jr, Banwell JG, Fresard KM \& Cummings JH (1987) Nitrogen in fecal bacterial, fiber and soluble fractions of patients with cirrhosis: effects of lactulose and lactulose plus neomycin. J Lab Clin Med 110, 259-263.

Wutzke KD, Heine WE, Plath C, Leitzmann P, Radke M, Mohr C, Richter I, Gulzow HU \& Hobusch D (1997) Evaluation of orocoecal transit time: a comparison of the lactose $\left[{ }^{13} \mathrm{C},{ }^{15} \mathrm{~N}\right]$ ureide ${ }^{13} \mathrm{CO}_{2^{-}}$and the hydrogen breath test in humans. Eur J Clin Nutr 51, 11-19. 